\title{
MONOLOGUES IN THE CONVERSATIONAL ERA: ASSESSING THE LEVEL OF DIALOGIC COMMUNICATION THAT BIG FIRMS ARE REACHING ON SOCIAL MEDIA
}

\author{
Monólogos en la era de la conversación: Evaluando \\ el nivel de comunicación dialógica de las grandes \\ empresas en los medios sociales
}

\section{Cristina Aced-Toledano and Ferran Lalueza}

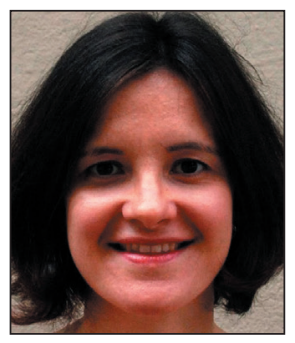

Cristina Aced-Toledano is an adjunct professor in the Department of Information and Communication Sciences at the Universitat Oberta de Catalunya (UOC) and lecturer in the Master Degree in Protocol and Public Relations at Universitat Pompeu Fabra. She also works as an independent PR and social media consultant since 2006. She holds a PhD in the Information and Knowledge Society Program from the UOC. She has published more than ten books on digital communication and PR and has published her works in several academic journals.

https://orcid.org/0000-0002-2732-5708

caced@uoc.edu

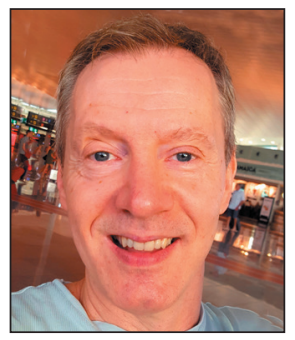

Ferran Lalueza is an associate professor in the Department of Information and Communication Sciences at the Universitat Oberta de Catalunya and an adjunct professor in the Department of Communication at the Universitat Pompeu Fabra (Barcelona, Spain). A former reporter, he also worked as a PR senior consultant at Burson-Marsteller for almost a decade. His academic qualifications include $\mathrm{aPD}$ and a MA in Journalism, and a Graduate Certificate in Information Sciences. He is a member of the research group GAME (Research Group in Learning, Media and Entertainment). https://orcid.org/0000-0002-7010-9795

flalueza@uoc.edu

Universitat Oberta de Catalunya Av. Tibidabo, 39-43. 08035 Barcelona, Spain

\begin{abstract}
Ibex 35 and Fortune 500 companies are still not fully utilizing the dialogic potential of social media. The percentage of companies with a low level of dialogic communication exceeds the percentage of companies with a high level in both groups, according to this study which assesses the level of dialogic communication developed by firms with their external audiences on blogs, Facebook and Twitter in an integrated way. Based on Kent \& Taylor's (1998) framework, a dialogic conceptual tool has been created, refined and applied to all the sample. The tool analyzes 73 variables on three dimensions: Presence, Content and Interactivity. Inter-method triangulation has been applied to carry out the research: virtual ethnography, critical discourse analysis (CDA) and interviews with experts.
\end{abstract}

\section{Keywords}

Social media; Social networks; Web 2.0; Dialogic communication; Dialogue; Conversation; Public relations; Best practices; Big companies.

\section{Resumen}

Las compañías del lbex 35 y del Fortune 500 aún no están utilizando plenamente el potencial dialógico de las redes sociales. El porcentaje de empresas con un nivel bajo de comunicación dialógica excede el porcentaje de empresas con un nivel alto en ambos grupos, según este estudio que evalúa, de una forma integrada, el nivel de comunicación dialógica alcanzado por las empresas con sus audiencias externas en blogs, Facebook y Twitter. En base al modelo de Kent \& Taylor (1998), se ha creado una herramienta conceptual dialógica, que se ha perfeccionado y aplicado a toda la muestra de estudio. La herramienta analiza 73 variables en tres dimensiones: presencia, contenido e interactividad. Se ha aplicado una triangulación metodológica para llevar a cabo la investigación: etnografía virtual, análisis crítico del discurso (CDA) y entrevistas con expertos. 


\section{Palabras clave}

Medios sociales; Redes sociales; Web 2.0; Comunicación dialógica; Diálogo; Conversación; Relaciones públicas; Buenas prácticas, Grandes empresas.

Aced-Toledano, Cristina; Lalueza, Ferran (2018). "Monologues in the conversational era: Assessing the level of dialogic communication that big firms are reaching on social media". El profesional de la información, v. 27, n. 6, pp. 1270-1280.

https://doi.org/10.3145/epi.2018.nov.10

\section{Introduction}

Social media are changing the way of making public relations (PR) (Wright, 2005; Wright; Hinson, 2013). The arrival of the web 2.0 opened the door towards fully interactive communication (Ingenhoff; Koelling, 2009; Jo; Kim, 2003), by allowing the receiver of the message to communicate back to the sender and thereby establishing a two-way communication. In this "dialogic communication", as it is called by Kent \& Taylor (2002), relationships are recovering the role they had at the beginnings of PR.

Some companies are seizing the opportunities social media offer for communicating with their publics, although most firms still have a one-direction communication on social media and are underutilizing the potential of these tools (Bortree; Seltzer, 2009; Capriotti; Moreno, 2007b; Hether, 2014; Kent, 2013; Kent; Taylor, 1998; Macnamara, 2010; Madichie; Hinson, 2013; McAllister-Spooner, 2009; Taylor; Kent; White, 2001; Watkins; Lewis, 2014; Xifra; Huertas, 2008).

Along the last years some research has studied communication opportunities provided by social media from a qualitative perspective, by adapting and applying the theoretical framework proposed by Kent \& Taylor (1998) to guide relationship-building on the Web. However, most of these studies focus on only one social platform and single-country companies (Capriotti; Pardo-Kuklinski, 2012; Kim et al., 2014; McAllister-Spooner, 2009; McCorkindale; Morgoch, 2013).

This research assesses the level of dialogic communication developed by companies with their external audiences on Facebook, Twitter and blogs in an integrated way, combining a qualitative approach with a quantitative one. With this aim, a dialogic conceptual tool based on Kent \& Taylor's (1998) framework has been created and applied to all the sample, which includes all the Ibex 35 companies, the main reference for the Spanish Stock Exchange nationally and internationally, and a selection of 20 Fortune 500 firms, an annual list published by Fortune magazine that ranks the top 500 United States companies by revenues.

\section{Literature review}

The searching of dialogue is not new in the public relations field (Kent, 2013; Kent; Taylor, 2002; Pieczka, 2011). First applications of dialogue as a framework for studying communication relationships are found in Ancient Greece, in the Socratic Dialogues of Plato (Kent; Taylor; Mcallister-Spooner, 2008). The term dialogue has appeared in the public relations bibliography for over four decades. In fact, the main objective of excellent public relations is to create a relationship and a dialogue across different stakeholders (Grunig; Grunig; Ehling, 1992; Ledingham; Bruning, 1998; Madichie; Hinson, 2013).

The novelty is that the Internet and social media provide new opportunities for building such relationships. As Ingenhoff \& Koelling (2009, p. 66) argue,

"the Internet provides organizations with the unique possibility of engaging publics in dialogue, a key characteristic of excellent public relations."

Social media make easy to establish a dialogue with publics because they enable a shift from the Web as passive information highway to a dynamic platform based precisely on dialogue (Kitchen; Panopoulos, 2010).

However, many companies are still having a one-direction communication on social media (Agozzino, 2015; Capriotti; Moreno, 2007a; Macnamara, 2010; Watkins, 2017; Xifra; Huertas, 2008). Already in the late 90's, Kent \& Taylor (1998, p. 331) predicted that

"the Web has great potential as a dialogic communication medium"

but it still remains

"underutilized by many organizations and underexamined by scholars as a tool for building organizational-public relationships" (Kent; Taylor, 1998, p. 322).

Social media have

"a tremendous untapped potential" (Kent, 2013, p. 340): the dialogic promise of the Web "has not yet been realized" (Kent; Taylor; Mcallister-Spooner, 2008; McAllister-Spooner, 2009).

Kent \& Taylor (1998) consider that dialogic communication is the theoretical framework for constructing relationships between organizations and their publics through websites. These authors (1998, p. 325) understand dialogic communication as

"any negotiated exchange of ideas and opinions".

They identify five principles of dialogic communication that organizations could follow to promote this kind of communication with their publics:

1) ease of interface: users should be able to easily navigate the site;

2) conservation of visitors: users should be encouraged to stay on the site;

3) generation of return visits: users should have an incentive for returning to the site over time; 
4) providing useful information to a variety of publics: users should find information that is specifically tailored to their needs, and

5) maintaining a dialogic loop: users should have opportunities and tools to ask questions and provide feedback.

Although this framework was born to be applied to websites, last years some studies have adapted it to social networks (Adams; McCorkindale, 2013; Agozzino, 2015; Bortree; Seltzer, 2009; Hether, 2014; Keller, 2013; Kim et al., 2014; Lim; Lee-Won, 2016; Muckensturm, 2013; Rybalko; Seltzer, 2010; Watkins, 2017).

Based on the previous literature review, three research questions are posed in this study:

RQ1. What level of dialogic communication have Ibex 35 companies in their use of blogs, Facebook and Twitter with their external audiences?

RQ2. What level of dialogic communication have Fortune 500 companies in their use of blogs, Facebook and Twitter with their external audiences?

RQ3. Based on the dialogic principles, what differences, if any, exist between the use of blogs, Facebook and Twitter by Ibex 35 companies and Fortune 500 companies?

\section{Methodology}

This research focuses on corporate blogs, Facebook pages and Twitter accounts. These platforms are selected because they are three of the most commonly used tools by companies according to previous studies (Aced; Lalueza, 2012; Barnes; Lescault; Wright, 2013; DiStaso; McCorkindale, 2013; Estudio de Comunicación, 2017; Villanueva; Orihuela, 2012; Wright; Hinson, 2013). In addition, they have a long history among the consolidated social media, which allows us to make a more thorough analysis. The simultaneous study of these three social media tools have allowed us to compare the corporate use across different platforms, as previous authors have done (DiStaso; McCorkindale, 2013; Kim et al., 2014; Kim; Kim; Nam, 2014; Luca, 2011). Moreover, from a scientific point of view, Facebook pages, Twitter profiles and corporate blogs have another strength: all the content published on them is public. This circumstance facilitates an exhaustive study of content published by firms. Lastly, focusing on three social media (Facebook, Twitter and blogs) makes it possible to study a wider sample of companies and to make a deep analysis of the dialogic aspects of their use of these three platforms.

The subjects for this study are Ibex 35 and Fortune 500 companies. The selected sample includes all the Ibex 35 companies (according to the Bolsa de Madrid as of September 1, 2014) and a selection of 20 Fortune 500 firms. All of them have a blog and/or a Facebook page and/or a Twitter profile.

At first, in order to identify the social media profiles of these companies, their websites were visited. Following this, three major Internet search engines (Google, Yahoo! and Bing), the Twitter's search tool and the Facebook's search tool were used subsequently to search for their social profiles because some companies do not include a link to all their social media profiles on their websites. It was decided to study a maximum of 2 blogs for each company, 2 Facebook pages and 4 kinds of Twitter profiles (where they exist): the company's corporate account, customer service profile, account targeted to press, and the profile of one of its products. Having applied these criteria, and after eliminating inactive profiles, a total of 31 blogs, 51 Facebook pages and 76 Twitter accounts were analyzed for six months, from September 2014 to February 2015.

Inter-method triangulation has been applied to carry out the research: virtual ethnography, critical discourse analysis (CDA) and interviews. Qualitative content analysis has been extensively used by scholars to assess the content published by organizations on Internet and to assess the presence or absence of dialogic features (Capriotti; González-Herrero, 2013; Kim et al., 2014; Losada-Díaz; Capriotti, 2015; Madichie; Hinson, 2013; McAllister-Spooner; Kent, 2009; Rybalko; Seltzer, 2010; Traynor et al., 2008; Waters; Lo, 2012). However, since not only the content on social networks is important but also the effectiveness and reactions in the audience (Watkins, 2017), a non-participant observation was carried while data was gathering and all the observations were collected in a Field Diary. According to Toledano (2017, p. 598),

"netnography could enrich PR studies into any community and social network that meets online".

As most previous researches on this field, Kent \& Taylor's (1998) framework has been the basis to develop a dialogic conceptual tool which allows companies to assess their use of social media. The original framework was created to study websites and this study has adapted it to blogs and social networks. Based on the non-participant observation, the CDA and the review of literature, a 73-item questionnaire was designed, organized in three dimensions: Presence (17 items), Content (35 items) and Interactivity (21 items).

\section{This study assesses the level of dialogic communication firms reach on social media}

Following the same system as applied in previous research (McCorkindale; Morgoch, 2013; Madichie; Hinson, 2013; Taylor; Kent; White, 2001), every variable is formulated in a dichotomous way in which the presence is positive and the absence is negative (yes $=1$, no $=0$ ), except for items related to the frequency of updating and the response time, where a scale of four possible answers was created (with marks from $1,0.5,0.25$ and 0 points). Final score of the questionnaire is calculated per dimension and the score of each dimension is calculated out of one.

The results of the questionnaire are connected with a five-point scale that ranks companies according to the level of dialogic communication they reach of social media. Called Poliscale and inspired by ancient Greek culture, in this scale organizations are placed in the Necropolis (if they have no presence on social media or their presence is not significant), the Thermal baths (if they are using social media without a clear goal or strategy), the Tavern (if they have a social media presence and interact with their audiences, but neglect content), 
Table 1. Scale of dialogic communication according to the use of social media

\begin{tabular}{|c|c|c|c|c|c|}
\hline & \multicolumn{5}{|c|}{ Level of dialogic communication } \\
\hline & \multicolumn{3}{|l|}{ Low } & \multicolumn{2}{|c|}{ High } \\
\hline & Necropolis & Thermal baths & Tavern & Bibliotheca (library) & Agora \\
\hline Presence & $<0.51$ & $\stackrel{+}{+}$ & $\begin{array}{c}+ \\
>0.50\end{array}$ & $\stackrel{+}{+}$ & $\begin{array}{c}+ \\
>0.50\end{array}$ \\
\hline Content & $<0.51$ & $<0.51$ & $<0.51$ & $\begin{array}{c}+ \\
>0.50\end{array}$ & $\begin{array}{c}+ \\
>0.50\end{array}$ \\
\hline Interactivity & $<0.51$ & $<0.51$ & $\begin{array}{c}+ \\
>0.50\end{array}$ & $<0.51$ & $\begin{array}{c}+ \\
>0.50\end{array}$ \\
\hline
\end{tabular}

the Bibliotheca/Library (if they use social media and take care of content, but forget to interact with their audiences) or the Agora (if they are making an optimal use of social media because they are concerned about generating valuable content and interacting with their audiences).

This typology starts from the assumption that a presence in social media is essential for companies. Hence, companies with less than 0.5 points on the Presence dimension are ranked automatically in the Necropolis, because it means that they have a low or a nonexistent presence on social media. Content is considered the second key dimension to assess the level of dialogue, because content is the first step to start a conversation. Finally, Interactivity is essential to reach a two-way communication with publics. Depending on the score in these three dimensions, companies are ranked from the Necropolis to the Agora, that is, from "very low" to "very high" level of dialogic communication (see Table 1).

The first version of this questionnaire was tested and first refined in November-December 2015 and in February 2016. In March-April 2016, 11 experts were interviewed and asked about the dialogic tool: 5 public relations (PR) \& social media consultants and 6 top PR scholars who have published papers on dialogic communication: prof. Kent and prof. Taylor, prof. McCorkindale, prof. Seltzer, prof. Waters and prof. Capriotti. These interviews helped the authors to refine the dialogic conceptual tool. The final version of the questionnaire was applied in May 2016 to all the sample, with data gathered in September 2014, February 2015 and February 2016. In addition, the dialogic conceptual tool has been tested on a sample of thirty-five subjects who applied the questionnaire to assess how the same two companies use social media. This test was useful to assess the reliability of the questionnaire although the sample is limited.

\section{Results}

Answering $\mathrm{RQ} 1$ and $\mathrm{RQ} 2$, results indicate that the dialogic level of the use of social media is higher in the Ibex $35 \mathrm{com}$ panies than in the Fortune 500 firms. 36\% of Ibex 35 firms and $20 \%$ of Fortune 500 firms have a high or very high level of dialogic communication on social media. However, the percentage of companies with a low level of dialogic communication exceeds the percentage of companies with a high level, both in the Ibex 35 and the Fortune 500 .

Although in general the level of dialogue is low, Spanish companies use social media in a more dialogic way than the North American ones. The third question examined the differences between the use of blogs, Facebook and Twitter by Ibex 35 companies and Fortune 500 companies. 27\% of Ibex 35 firms and $20 \%$ of Fortune 500 companies have a very high level of dialogic communication on social media. They were placed in the Agora, which is the top dimension in the Poliscale, the scale created in this research that ranks firms according to their use of social media and dialogic communication level. No Ibex 35 company but $20 \%$ of Fortune 500 firms were placed in the Necropolis, which is the lowest dimension in the Poliscale and include the companies that have no presence or a not significant one on social media.

Table 2 summarizes the results of the application of the dialogic tool to all the sample in September 2014, February 2015 and February 2016. The main results of each dimension (Presence, Content and Interactivity) are exposed below. All the results are from February 2016 and compared with September 2014 and/or February 2015 when it is outstanding. Tables 3 to 5 summarize the results of the study.

Table 2. Results of the application of the dialogic conceptual tool (\%)

\begin{tabular}{|c|c|c|c|c|c|c|}
\hline & \multicolumn{3}{|c|}{ Ibex 35} & \multicolumn{3}{|c|}{ Fortune 500} \\
\hline & September 2014 & February 2015 & February 2016 & September 2014 & February 2015 & February 2016 \\
\hline Agora & 9.09 & 13.64 & 27.27 & 20.00 & 20.00 & 20.00 \\
\hline Bibliotheca & 13.64 & 13.64 & 9.09 & 6.67 & 0 & 0 \\
\hline Tavern & 36.37 & 36.37 & 18.18 & 13.33 & 20.00 & 26.67 \\
\hline Thermal baths & 40.91 & 36.37 & 45.45 & 40.00 & 40.00 & 33.33 \\
\hline Necropolis & 0 & 0 & 0 & 20.00 & 20.00 & 20.00 \\
\hline
\end{tabular}


Table 3. Summary results of 'Presence' (\%)

\begin{tabular}{|c|c|c|c|c|c|c|}
\hline & \multicolumn{3}{|c|}{ Ibex 35} & \multicolumn{3}{|c|}{ Fortune 500} \\
\hline & Sept. 2014 & Feb. 2015 & Feb. 2016 & Sept. 2014 & Feb. 2015 & Feb. 2016 \\
\hline \multicolumn{7}{|l|}{ Blogs } \\
\hline Available in more than one language & 18.18 & 18.18 & 18.18 & 0 & 0 & 0 \\
\hline Categories & 68.18 & 68.18 & 63.64 & 40.00 & 40.00 & 40.00 \\
\hline Search engine & 59.09 & 59.09 & 59.09 & 40.00 & 40.00 & 40.00 \\
\hline Navigation menu & 50.00 & 50.00 & 45.45 & 40.00 & 40.00 & 40.00 \\
\hline \multicolumn{7}{|l|}{ Facebook } \\
\hline Content in more than one language & 4.55 & 9.09 & 13.64 & 0 & 0 & 0 \\
\hline Custom tabs & 95.45 & 95.45 & 95.45 & 80.00 & 80.00 & 80.00 \\
\hline Custom page's profile picture & 95.45 & 95.45 & 95.45 & 93.33 & 93.33 & 93.33 \\
\hline Custom cover photo & 95.45 & 95.45 & 95.45 & 93.33 & 93.33 & 93.33 \\
\hline \multicolumn{7}{|l|}{ Twitter } \\
\hline Content in more than one language & 13.64 & 18.18 & 18.18 & 0 & 0 & 0 \\
\hline Custom profile picture & 100.00 & 100.00 & 100.00 & 100.00 & 100.00 & 100.00 \\
\hline Custom header photo & 100.00 & 100.00 & 100.00 & 100.00 & 100.00 & 100.00 \\
\hline
\end{tabular}

\subsection{Presence}

$46 \%$ of Ibex 35 companies had at least one corporate blog. $18 \%$ of these blogs were available in more than one language. 6 out 10 had categories and a search engine and half of the analyzed blogs had a navigation menu. $47 \%$ of Fortune 500 companies had at least one corporate blog. $40 \%$ of Fortune 500 companies had categories on blog, included a navigation menu and organized posts by categories.

$60 \%$ of Ibex 35 companies and $70 \%$ of Fortune 500 firms had at least one fanpage on Facebook. 14\% of Ibex 35 firms published content in more than one language on Facebook, which represented a 4\% increase over February 2015 and a 9\% increase over September 2014. 95\% of Ibex 35 Facebook pages had personalized the page's profile picture and the cover photo. 80\% of Fortune 500 Facebook pages had custom tabs. 93\% had a custom page's profile picture and a custom cover photo on Facebook.

6 out of $10 \mathrm{lbex} 35$ companies and Fortune 500 firms had at least one Twitter account. 18\% of Ibex 35 companies published tweets in more than one language in February 2016 and February 2015, which represented a 4\% increase over September 2014. All the companies had a custom profile picture and a custom header photo on Twitter.

\subsection{Content}

With respect to the kind of content published on corporate blogs, $73 \%$ of Ibex 35 companies shared textual content, $41 \%$ videos, $73 \%$ photos and $9 \%$ infographics. No company published podcasts. The use of text and photos remained stable since September 2014 and the use of videos and infographics grew over time.

In $41 \%$ of Ibex 35 blogs, author was identified on posts in February 2016. This represented an increase of 4.55 points compared to September 2014 and February 2015. 80\% of Ibex 35 blogs had been updated during last week (last 0-7 days), $0 \%$ during last two weeks (last 8-14 days), 6\% during last month (last 15-30 days) and 13\% had not updated for more than a month.
As for the sort of content published on corporate blogs by Fortune 500 companies, $47 \%$ of them shared textual content, $27 \%$ shared videos, $47 \%$ photos and $27 \%$ infographics. No company published podcasts. The use of text, photos and video remained stable and the use of infographics grew.

In 4 out of 10 Fortune 500 blogs, author was identified on posts (with any of this data: name, initials, position, etc.). In February 2016, all the Fortune 500 blogs had been updated during last week (last 0-7 days). This data remained stable from September 2014.

This study expands the Kent \& Taylor's dalogic framework created in 1998 for websites

With regard to the kind of content published on Facebook pages, 95\% of Ibex 35 companies shared textual content, $59 \%$ videos, $95 \%$ photos and $4 \%$ infographics. No company published podcasts. The use of text and photos remained stable since September 2014 and the use of videos and infographics grew over time.

9 out of 10 Ibex 35 firms published company's data on the fanpage information section and $41 \%$ provided contact information. In no case author's post was identified. $90 \%$ of Ibex 35 Facebook pages had been updated during last three days and 9\% during last week (last 4-7 days).

Regarding the format of content published on Facebook pages by Fortune 500 firms, results indicate that $93 \%$ of them published textual content, $47 \%$ videos and $93 \%$ photos. No company published podcasts or infographics. The use of text and photos, remained stable since September 2014 and the use of videos grew over time.

9 out of 10 Fortune 500 firms published company's data on the fanpage information section and 33\% provided contact information. In no case author's post was identified. $86 \%$ of Fortune 500 Facebook pages had been updated during last three days and $14 \%$ during last week (last 4-7 days). 
Regarding the kind of content published on Twitter pages by Ibex 35 firms, all of them shared textual content, $23 \%$ videos, $95 \%$ photos and $18 \%$ infographics. No company published podcasts. The use of text remains stable since September 2014. The use of videos, photos and infographics grows over time. $86 \%$ of Ibex 35 Twitter accounts had been updated last 24 hours and $14 \%$ during last three days.
As for the sort of content published on Twitter pages, all the Fortune 500 companies shared textual content, $27 \%$ videos and $87 \%$ photos. No company published neither podcasts nor infographics in February 2016. The use of text and photos remains stable, the use of videos grew over time and the use of podcasts decreased since September 2014.

Table 4. Summary results of 'Content' (\%)

\begin{tabular}{|c|c|c|c|c|c|c|}
\hline & \multicolumn{3}{|c|}{ Ibex 35} & \multicolumn{3}{|c|}{ Fortune 500} \\
\hline & Sept. 2014 & Feb. 2015 & Feb. 2016 & Sept. 2014 & Feb. 2015 & Feb. 2016 \\
\hline \multicolumn{7}{|l|}{ Blogs } \\
\hline \multicolumn{7}{|l|}{ Content format } \\
\hline Text & 72.73 & 72.73 & 68.18 & 46.67 & 46.67 & 46.67 \\
\hline Audio (podcast) & 0 & 0 & 0 & 0 & 0 & 0 \\
\hline Video & 31.82 & 36.36 & 36.36 & 26.67 & 26.67 & 26.67 \\
\hline Photo & 72.73 & 72.73 & 68.18 & 46.67 & 46.67 & 46.67 \\
\hline Infographic & 0 & 4.55 & 9.09 & 20.00 & 26.67 & 26.67 \\
\hline \multicolumn{7}{|l|}{ Updating frequency } \\
\hline Last week (0-7 days) & 87.50 & 81.25 & 80.00 & 100 & 100 & 100 \\
\hline Last two weeks (8-14 days) & 6.25 & 6.25 & 0 & 0 & 0 & 0 \\
\hline Last month (15-30 days) & 6.25 & 6.25 & 6.67 & 0 & 0 & 0 \\
\hline Not updated for more than a month & 0 & 6.25 & 13.33 & 0 & 0 & 0 \\
\hline "About me" section & 22.73 & 22.73 & 18.18 & 26.67 & 26.67 & 26.67 \\
\hline Contact information & 18.18 & 18.18 & 18.18 & 13.33 & 13.33 & 13.33 \\
\hline Author is identified & 36.36 & 36.36 & 40.91 & 46.67 & 46.67 & 46.67 \\
\hline \multicolumn{7}{|l|}{ Facebook } \\
\hline \multicolumn{7}{|l|}{ Content format } \\
\hline Text & 95.45 & 95.45 & 95.45 & 93.33 & 93.33 & 93.33 \\
\hline Audio (podcast) & 0 & 0 & 0 & 0 & 0 & 0 \\
\hline Video & 27.27 & 54.55 & 59.09 & 13.33 & 46.67 & 46.67 \\
\hline Photo & 95.45 & 95.45 & 95.45 & 93.33 & 93.33 & 93.33 \\
\hline Infographic & 0 & 0 & 4.55 & 0 & 0 & 0 \\
\hline \multicolumn{7}{|l|}{ Updating frequency } \\
\hline Last 3 days ( $0-3$ days) & 85.71 & 90.48 & 90.48 & 85.71 & 85.71 & 85.71 \\
\hline Last week (4-7 days) & 14.29 & 9.52 & 9.52 & 14.29 & 14.29 & 14.29 \\
\hline Last two weeks (8-14 days) & 0 & 0 & 0 & 0 & 0 & 0 \\
\hline Not updated for more than two weeks & 0 & 0 & 0 & 0 & 0 & 0 \\
\hline Company's data on information section & 95.45 & 95.45 & 95.45 & 93.33 & 93.33 & 93.33 \\
\hline Contact information & 40.91 & 40.91 & 40.91 & 33.33 & 33.33 & 33.33 \\
\hline Use of hashtags & 18.18 & 18.18 & 27.27 & 26.67 & 40.00 & 40.00 \\
\hline \multicolumn{7}{|l|}{ Twitter } \\
\hline \multicolumn{7}{|l|}{ Content format } \\
\hline Text & 100 & 100 & 100 & 100 & 100 & 100 \\
\hline Audio (podcast) & 0 & 0 & 0 & 6.67 & 0 & 0 \\
\hline Video & 4.55 & 9.09 & 22.73 & 13.33 & 26.67 & 26.67 \\
\hline Photo & 90.91 & 90.91 & 95.45 & 86.67 & 86.67 & 86.67 \\
\hline Infographics & 4.55 & 4.55 & 18.18 & 0 & 0 & 0 \\
\hline \multicolumn{7}{|l|}{ Updating frequency } \\
\hline Last 24 hours & 81.82 & 86.36 & 86.36 & 86.67 & 86.67 & 86.67 \\
\hline Last three days (0-3 days) & 18.18 & 13.64 & 13.64 & 13.33 & 13.33 & 13.33 \\
\hline Last week (4-7 days) & 0 & 0 & 0 & 0 & 0 & 0 \\
\hline Not updated for more than a week & 0 & 0 & 0 & 0 & 0 & 0 \\
\hline Company's information on bio & 100 & 100 & 100 & 100 & 100 & 100 \\
\hline Use of hashtags & 81.82 & 81.82 & 100 & 93.33 & 100 & 100 \\
\hline
\end{tabular}


All the firms published company's data on Twitter bio, both in Ibex 35 and Fortune 500. In no case author was identified on Twitter.

When analyzing if companies publish different content, results indicated that $86 \%$ of Ibex 35 companies published different content on Twitter, Facebook and blog (at least on 2 of these platforms) in February 2016, which meant a fall of $9 \%$ over February 2015 and an increase of $14 \%$ over September 2014. 93\% of Fortune 500 companies published different content on Twitter, Facebook and blog (at least on 2 of them) in February 2016, in February 2015 and in September 2014.

\subsection{Interactivity}

Focusing on the interactivity, $56 \%$ of Ibex 35 blogs had not received any comment. Of the comments received, $31 \%$ were not answered and $12 \%$ were answered in less than a week. Just in $9 \%$ of Ibex 35 blogs, answers to comments were tailored in February 2016. This represented an increase of 4 points compared to September 2014. Paying attention to other ways to interact in blogs, it was found that 6 out of $10 \mathrm{lbex} 35 \mathrm{com}-$ panies included direct links to social networks profiles and facilities to share the posts on social media. $27 \%$ of Ibex 35 blogs included Call to Action (CTA) such as "continue reading", "click here", "please comment", etc., on posts.

$43 \%$ of Fortune 500 blogs had not received any comment. Of the comments received, $43 \%$ were not answered and $14 \%$ were answered in less than a week. Analyzing other ways to interact, $47 \%$ of Fortune 500 companies included direct links to social networks profiles on blog and included facilities to share the posts on social media. 2 out of 10 blogs included CTA on posts.

Table 5. Summary results of 'Interactivity' (\%)

\begin{tabular}{|c|c|c|c|c|c|c|}
\hline & \multirow{2}{*}{\multicolumn{3}{|c|}{ Ibex 35}} & & & \\
\hline & & & & \multicolumn{3}{|c|}{ Fortune 500} \\
\hline & Sept. 2014 & Feb. 2015 & Feb. 2016 & Sept. 2014 & Feb. 2015 & Feb. 2016 \\
\hline \multicolumn{7}{|l|}{ Blogs } \\
\hline \multicolumn{7}{|l|}{ Comments are answered } \\
\hline In less than 24 hours & 0 & 0 & 0 & 0 & 0 & 0 \\
\hline In less than a week & 6.25 & 12.50 & 13.33 & 0 & 14.29 & 0 \\
\hline In more than a week & 0 & 0 & 0 & 0 & 0 & 0 \\
\hline Not answered & 50.00 & 25.00 & 33.33 & 57.14 & 57.14 & 42.86 \\
\hline Answers to comments are tailored & 4.55 & 9.09 & 9.09 & 0 & 0 & 0 \\
\hline Direct links to social networks & 68.18 & 68.18 & 68.18 & 46.67 & 46.67 & 46.67 \\
\hline Facilities to share blog posts on social media & 68.18 & 68.18 & 68.18 & 46.67 & 46.67 & 46.67 \\
\hline Call To Action (CTA) on posts & 31.82 & 27.27 & 27.27 & 20.00 & 20.00 & 20.00 \\
\hline \multicolumn{7}{|l|}{ Facebook } \\
\hline Company allow to write in the fanpage's wall & 31.82 & 45.45 & 50.00 & 53.33 & 53.33 & 73.33 \\
\hline \multicolumn{7}{|l|}{ Comments are answered } \\
\hline In less than 24 hours & 28.57 & 28.57 & 23.81 & 28.57 & 42.86 & 50.00 \\
\hline In less than a week & 19.05 & 19.05 & 14.29 & 21.43 & 21.43 & 7.14 \\
\hline In more than a week & 0 & 0 & 0 & 0 & 0 & 0 \\
\hline Not answered & 33.33 & 33.33 & 42.86 & 50.00 & 35.71 & 42.86 \\
\hline Answers to comments are tailored & 45.45 & 45.45 & 40.91 & 46.67 & 53.33 & 53.33 \\
\hline Posts are liked & 95.45 & 95.45 & 95.45 & 93.33 & 93.33 & 93.33 \\
\hline Posts are shared & 90.91 & 90.91 & 90.91 & 93.33 & 93.33 & 93.33 \\
\hline CTA on posts & 50.00 & 50.00 & 50.00 & 40.00 & 53.33 & 53.33 \\
\hline People is tagged & 0 & 0 & 0 & 0 & 0 & 0 \\
\hline \multicolumn{7}{|l|}{ Twitter } \\
\hline \multicolumn{7}{|l|}{ Comments are answered } \\
\hline In less than 24 hours & 22.73 & 22.73 & 22.73 & 6.67 & 6.67 & 6.67 \\
\hline In less than a week & 9.09 & 4.55 & 4.55 & 6.67 & 13.33 & 13.33 \\
\hline In more than a week & 0 & 0 & 0 & 0 & 0 & 0 \\
\hline Not answered & 4.55 & 4.55 & 4.55 & 0 & 0 & 0 \\
\hline Answers to comments are tailored & 31.82 & 27.27 & 27.27 & 13.33 & 13.33 & 13.33 \\
\hline Retweets (RT) are published & 68.18 & 72.73 & 72.73 & 86.67 & 93.33 & 93.33 \\
\hline Tweets are RT & 95.45 & 95.45 & 95.45 & 93.33 & 93.33 & 93.33 \\
\hline Tweets are liked & 100 & 100 & 100 & 93.33 & 93.33 & 93.33 \\
\hline CTA on tweets & 72.73 & 72.73 & 72.73 & 66.67 & 73.33 & 73.33 \\
\hline People is tagged & 0 & 0 & 4.55 & 0 & 0 & 0 \\
\hline
\end{tabular}


Focusing on Facebook, half of Ibex 35 firms allowed users to write in their fanpage wall in February 2016, which represented a 4\% increase over February 2015 and a 18\% over September 2014. In 19\% of Ibex 35 Facebook pages there were not comments. $43 \%$ of Ibex 35 firms did not answer the comments received and $24 \%$ answered them in less than 24 hours. 4 out of 10 answers to Facebook comments were tailored. 9 out of 10 Facebook posts were liked, the same number which was shared by users. Half of Ibex 35 companies included CTA on Facebook posts.

Analyzing Fortune 500 Facebook pages, 73\% of them allowed users to write in their fanpage wall in February 2016. It represented a 20\% increase over February 2015 and September 2014. All the Fortune 500 Facebook pages received comments. $43 \%$ of Fortune 500 firms did not answer the comments received and $50 \%$ answered the comments in less than 24 hours. 9 out of 10 Facebook were liked and 93\% are shared by users. Half of Fortune 500 companies included CTA on Facebook posts.

Although Internet is multimedia, textual content is the most common used in social media

In relation with interactivity on Twitter, $73 \%$ of Ibex 35 companies published retweets. All the Ibex 35 companies obtained some "like" on their tweets. 9 out of 10 Ibex 35 companies obtained retweets of their tweets and 7 out 10 included CTA on their tweets. 4\% of Ibex 35 firms tagged people on their tweets in February 2016, a 4\% increase over last year.

$68 \%$ of Ibex 35 companies did not receive mentions on Twitter. 4\% of Ibex 35 firms did not answer the mentions received. $27 \%$ answered them with a custom reply and $23 \%$ answered to mentions received on Twitter in less than 24 hours.

Analyzing the activity of Fortune 500 firms on Twitter, 93\% of them published retweets. 9 out of 10 Fortune 500 companies obtained some "like" on their tweets and/or obtained retweets of their tweets. $73 \%$ of Fortune 500 companies included CTA on their tweets.

8 out of 10 Fortune 500 companies did not receive mentions on Twitter. 13\% answered to mentions received on Twitter with a custom reply and $7 \%$ answered to mentions in less than 24 hours.

\section{Discussion and conclusions}

This study concludes that Ibex 35 and Fortune 500 companies are still not fully utilizing the dialogic potentials of social media, in line with previous researches (Bortree; Seltzer, 2009; Kim et al., 2014; McAllister-Spooner; Kent, 2009; McAllister-Spooner, 2012; Rybalko; Seltzer, 2010). Although 3 out of 10 Ibex 35 firms had a very high level of dialogic communication on social media (they are placed in the Agora, the top dimension in the Poliscale) in February 2016 -and this represents an increase over previous yearsand 2 out of 10 Fortune 500 firms had a very high level of dialogic communication, the percentage of companies with a low level of dialogic communication (which are placed in the Thermal baths or Necropolis ) exceeds the percentage of companies with a high level, both in the Ibex 35 and the Fortune 500. The Agora is still an aspiration for most companies under study.

The social media preferred by the Fortune 500 companies were Facebook (70\%) and Twitter (62\%). The Ibex 35 firms used Twitter (62\%) and Facebook (60\%) at the same level. In both cases, blogs appeared in third place (45\%). The use of several social media is the most basic and important thing, since having presence is the starting point of a dialogue. As previously explained, a scarce presence in social media leads the company directly to the lowest category in the Poliscale: the Necropolis.

Content is the first step to start a conversation, and for this reason it is considered the second key dimension to assess the level of dialogue in this typology. In fact, in the Agora we find the companies that are concerned about generating valuable content. Although Internet is multimedia, textual content is the most common used by companies on social media, followed by photos and videos. The use of videos and infographics grows over time. No company published podcasts: previous studies also show that the use of audio content is very low (Waters; Williams, 2011).

The frequency of updating is another of the aspects that are considered in the content dimension of the questionnaire. Twitter was the social network which was more often updated, followed by Facebook and blogs. 8 out 10 Ibex 35 and Fortune 500 companies published tweets every day, and nearly $95 \%$ of the firms of the sample updated Facebook pages during last week. Weekly updating was also the most common in blogs. The frequency of updating social networks was very similar in Ibex 35 and Fortune 500, which differs from the results of Losada-Díaz \& Capriotti recent study (2015).

Authorship is a key aspect in blogs: in 4 out of 10 analyzed blogs, author was identified. However, this information was not provided in any case in Facebook or Twitter. Previous research (Aced; Lalueza, 2016; Lee; Hwang; Lee, 2006; Xifra; Huertas, 2008) suggests that impersonal corporate blogs are not well accepted by the community because they are seen as marketing tools.

In this study, there are several meaningful findings on interaction, which is the essential dimension to reach a two-way communication with publics: it is impossible to reach the Agora without interacting with publics. Above all, consistent with the findings of previous research (Aced; Lalueza, 2016; McCorkindale, 2010; Rybalko; Seltzer, 2010; Xifra; Huertas, 2008), the level of interaction with the publics is still very low and many companies do not seem to be interested in conversation: comments were not answered in 3 out of 10 Ibex 35 blogs, and 4 out of 10 Fortune 500 blogs. In Facebook, 4 out of 10 companies did not answer the comments, both in Ibex 35 and Fortune 500. In Twitter, 6 out of 10 Ibex 35 firms, and 8 out of 10 Fortune 500 companies did not receive any mention, which is the first step to start a conversation. 
"Likes" and "shares/retweets" were the most common method of interaction in Facebook and Twitter (9 out of 10 publications were liked and/or shared by users in both social networks either in Fortune 500 or Ibex 35 companies).

Most companies published different content on Twitter, Facebook and blog (at least on 2 of these platforms). However, the ideal would be that all the content was different in each social media and adapted to the features of each platform, as previous research suggest (Aced; Lalueza, 2016).

To sum up, it should be noted that this research shows that there is not a big difference between the use of social media that make the North American and Spanish companies, as previous studies point out (Aced; Lalueza, 2016; Losada-Díaz; Capriotti, 2015). Results of this research show that the dialogic level of the use of social media is higher in the Ibex 35 companies than in the Fortune 500 firms.

Although few companies are placed in the Necropolis (no Ibex 35 firms but $20 \%$ of Fortune 500 firms), which is the lowest category in the Poliscale, most firms are placed in the Thermal baths (45\% of Ibex 35 and 33\% of Fortune 500 fir$\mathrm{ms})$, which is the second level of low dialogue in this typology and we find companies that believe that merely being on social platforms is good enough to obtain results, without a clear goal and strategy. About $20 \%$ of companies both in Ibex 35 and Fortune 500 are ranked in the Tavern, where are placed firms that have social media presence and interact with their audiences but neglect the content. No Fortune 500 firms and only $9 \%$ of Ibex 35 companies are placed in the Bibliotheca: these companies take care of content but forget to interact with their publics. These data might seem encouraging, but companies should aspire to be ranked in the Agora if they want to fulfill the promise of dialogue offered by social media. Agora is only available to those companies with a strong presence that create valuable content to interact with their audiences: only they might achieve the desired two-way communication in social media.

\section{A dialogic conceptual tool has been crea-} ted, refined and applied

\subsection{Limitations}

All research has its limitations and this one is no exception. The fact of limiting the number of blogs and social networks profiles under study is one limitation of this study. As previously explained, it was decided to study a maximum 2 blogs, 2 Facebook pages and 4 Twitter accounts for each company of the sample. In addition, the size of the sample is also limited. All the Ibex 35 companies were included in the study but only a selection of 20 Fortune 500 firms with blog and/or a Facebook page and/or a Twitter profile were studied.

Regarding the questionnaire and the creation of the scale, 11 experts on social media and public relations were interviewed and it had been tested on a sample of thirty-five subjects. In the future, more expert interviews could be done and the tool could be tested with a larger number of participants.
Despite these limitations, this research also makes a significant contribution to knowledge in public relations. The results of this study have theoretical and managerial implications for both researchers and practitioners.

\subsection{Future directions}

This study extends the investigation of online dialogic communication by examining in an integrated way the application of dialogic principles on blogs, Facebook and Twitter by companies. It expands and updates the Kent \& Taylor's dialogic framework created in 1998 to be applied in websites.

\section{Companies are still not fully utilizing the dialogic potential of social media}

The creation of a dialogic conceptual tool (a questionnaire) and a scale (the Poliscale) which ranks firms according to their use of social media provide researchers a theoretical tool for expanding the study of social media from a public relations approach. Furthermore, both the questionnaire and the Poliscale are proposed as tools that might help standardize the qualitative evaluation of how companies are using social media. The questionnaire allows practitioners to evaluate how its firm is using social media in terms of Presence, Interactivity and Content, as well as to categorize it according to this use. Once the questionnaire is applied, the results rank the company in the Poliscale, the scale of social media use. According to the category where it is located, the company obtains useful information for improving its social media strategy and increasing the level of dialogue with publics. And not only that: the practitioners can apply the questionnaire to the competitors and obtain a very useful benchmark.

In the future, other social networks such as LinkedIn, Instagram or Snapchat might be added to the study, expanding and adapting the questionnaire to include these platforms.

Furthermore, the methodology of this research, the questionnaire and the Poliscale might be applied to other markets and countries. Firstly, the study might be replicated with firms listed in the stock exchanges indexes of other economic contexts. Secondly, the investigation might be extended to other developed and developing countries. And the model is not only applicable at companies, it can also be applied to other types of organizations, such as non-profits and universities.

\section{References}

Aced, Cristina; Lalueza, Ferran (2012). "How (Spanish) companies are using social media: a proposal for a qualitative assessment tool". In: Intl Conf on Social e-xperience. Barcelona.

Aced, Cristina; Lalueza, Ferran (2016). “¿Qué contenidos publican las empresas en los medios sociales? Análisis crítico del discurso de las compañías del lbex 35 y del Fortune 500 en blogs corporativos, Facebook y Twitter". Revista internacional de relaciones públicas, v. 6, n. 11, pp. 135-154. https://doi.org/10.5783/RIRP-11-2016-08-135-154

Adams, Amelia; McCorkindale, Tina (2013). “Dialogue and 
transparency: A content analysis of how the 2012 presidential candidates used Twitter". Public relations review, v. 39, n. 4, pp. 357-359.

https://doi.org/10.1016/j.pubrev.2013.07.016

Agozzino, Alisa (2015). Dialogic communication through "pinning": An analysis of top 10 most-followed organizations' Pinterest profiles". Public relations journal, v. 9, n. 3. https://goo.gl/ucjPmU

Barnes, Nora-Ganim; Lescault, Ava M.; Wright, Stephanie (2013). "2013 Fortune 500 are bullish on social media : Big companies get excited about Google+, Instagram, Foursquare and Pinterest". UMass Dartmouth, pp. 1-9.

https://www.umassd.edu/media/umassdartmouth/cmr/ studiesandresearch/2013_Fortune_500.pdf

Bortree, Denise-Sevic; Seltzer, Trent (2009). "Dialogic strategies and outcomes: An analysis of environmental advocacy groups' Facebook profiles". Public relations review, v. 35, n. 3, pp. 317-319.

https://doi.org/10.1016/j.pubrev.2009.05.002

Capriotti, Paul; González-Herrero, Alfonso (2013). “Managing media relations in museums through the Internet: $A$ model of analysis for online pressrooms in museums". Museum management and curatorship, v. 28, n. 4, pp. 413-429. https://doi.org/10.1080/09647775.2013.831246

Capriotti, Paul; Moreno, Ángeles (2007a). “Communicating corporate responsibility through corporate web sites in Spain". Corporate communications, v. 12, n. 3, pp. 221-237. https://doi.org/10.1108/13563280710776833

Capriotti, Paul; Moreno, Ángeles (2007b). “Corporate citizenship and public relations: The importance and interactivity of social responsibility issues on corporate websites". Public relations review, v. 33, n. 1, pp. 84-91.

https://doi.org/10.1016/j.pubrev.2006.11.012

Capriotti, Paul; Pardo-Kuklinski, Hugo (2012). “Assessing dialogic communication through the Internet in Spanish museums". Public relations review, v. 38, n. 4, pp. 619-626. http://doi.org/10.1016/j.pubrev.2012.05.005

DiStaso, Marcia W.; McCorkindale, Tina (2013). "A benchmark analysis of the strategic use of social media for Fortune's most admired US companies on Facebook, Twitter and YouTube". Public relations journal, v. 7, n. 1, pp. 1-33. https://goo.gl/p9FbqJ

Estudio de Comunicación (2017). Presencia de las empresas del lbex 35 en el entorno digital.

https://goo.gl/sj6FET

Grunig, Larissa A.; Grunig, James E.; Ehling, William P. (1992). "What is an effective organization?" In: Grunig, James E. (ed.). Excellence in public relations and communication management. Hillsdale, NJ: Lawrence Erlbaum Associates, pp. 65-90. ISBN: 9780805802276

Hether, Heather-Jane (2014). "Dialogic communication in the health care context: A case study of Kaiser Permanente's social media practices". Public relations review, v. 40, n. 5, pp. 856-858.

https://doi.org/10.1016/j.pubrev.2014.07.007
Ingenhoff, Diana; Koelling, Martina (2009). "The potential of Web sites as a relationship building tool for charitable fundraising NPOs". Public relations review, v. 35, n. 1, pp. 66-73. https://core.ac.uk/download/pdf/79427382.pdf https://doi.org/10.1016/j.pubrev.2008.09.023

Jo, Samsup; Kim, Yungwook (2003). "The effect of web characteristics on relationship building". Journal of public relations research, v. 15, n. 3, pp. 199-223. https://doi.org/10.1207/S1532754XJPRR1503_1

Keller, Heidi (2013). You really like me: Dialogic social media use in organizational communication. Gonzaga University.

Kent, Michael L. (2013). "Using social media dialogically: Public relations role in reviving democracy". Public relations review, v. 39, n. 4, pp. 337-345.

https://doi.org/10.1016/j.pubrev.2013.07.024

Kent, Michael L.; Taylor, Maureen (1998). "Building dialogic relationships through the world wide web". Public relations review, v. 24, n. 3, pp. 321-334.

https://doi.org/10.1016/S0363-8111(99)80143-X

Kent, Michael L.; Taylor, Maureen (2002). “Toward a dialogic theory of public relations". Public relations review, v. 28, n. 1, pp. 21-37.

https://doi.org/10.1016/S0363-8111(02)00108-X

Kent, Michael L.; Taylor, Maureen; Mcallister-Spooner, Sheila M. (2008). "Research in dialogic theory and public relations". In: Mathur, R. (ed.), Public relations: An ethics engagement. New Delhi: Icfai University Press, pp. 1-17.

Kim, Daejoong; Chun, Heasun; Kwak, Youngsun; Nam, Yoonjae (2014). "The employment of dialogic principles in website, Facebook, and Twitter platforms of environmental nonprofit organizations". Social science computer review, v. 32, n. 5, pp. 590-605.

https://doi.org/10.1177/0894439314525752

Kim, Daejoong; Kim, Jang-Hyun; Nam, Yoonjae (2014). "How does industry use social networking sites? An analysis of corporate dialogic uses of Facebook, Twitter, YouTube, and LinkedIn by industry type". Quality and quantity, v. 48, n. 5, pp. 2605-2614.

https://doi.org/10.1007/s11135-013-9910-9

Kitchen, Philip J.; Panopoulos, Anastasios (2010). “Online public relations: The adoption process and innovation challenge, a Greek example". Public relations review, v. 36, n. 3, pp. 222-229.

https://doi.org/10.1016/j.pubrev.2010.05.002

Ledingham, John A.; Bruning, Stephen D. (1998). "Relationship management in public relations: Dimensions of an organization-public relationship". Public relations review, v. 24, n. 1, pp. 55-65.

https://doi.org/10.1016/S0363-8111(98)80020-9

Lee, Sang; Hwang, Taewon; Lee, Hong-Hee (2006). "Corporate blogging strategies of the Fortune 500 companies". Management decision, v. 44, n. 3, pp. 316-334.

https://goo.gl/9ci77H

https://doi.org/10.1108/00251740610656232

Lim, Young-Shin; Lee-Won, Roselyn J. (2016). "When re- 
tweets persuade: The persuasive effects of dialogic retweeting and the role of social presence in organizations' Twitter-based communication". Telematics and informatics, v. 34, n. 5, pp. 422-433.

https://doi.org/10.1016/j.tele.2016.09.003

Losada-Díaz, Juan-Carlos; Capriotti, Paul (2015). “La comunicación de los museos de arte en Facebook: comparación entre las principales instituciones internacionales y españolas". Palabra, v. 18, n. 3, pp. 889-904.

https://doi.org/10.5294/pacla.2015.18.3.11

Luca, Philip (2011). Social media dialogue: An analysis of the social media presence of selected Fortune 500 companies. Liberty University.

https://core.ac.uk/download/pdf/58824128.pdf

Macnamara, Jim (2010). "Public communication practices in the Web 2.0-3.0 mediascape : The case for PRevolution". PRism, v. 7, n. 3, pp. 1-13.

Madichie, Nmandi O.; Hinson, Robert (2013). "A critical analysis of the "dialogic communications" potential of sub-Saharan African police service websites". Public relations review, v. 40, n. 2, pp. 338-350.

https://doi.org/10.1016/j.pubrev.2013.10.009

McAllister-Spooner, Sheila M. (2009). "Fulfilling the dialogic promise: A ten-year reflective survey on dialogic internet principles". Public relations review, v. 35, n. 3, pp. 320-322. https://doi.org/10.1016/j.pubrev.2009.03.008

McAllister-Spooner, Sheila M. (2012). “How the world's top universities provide dialogic forums for marginalized voices". Public relations review, v. 38, n. 2, pp. 319-327.

https://doi.org/10.1016/j.pubrev.2011.12.010

McAllister-Spooner, Sheila M.; Kent, Michael L. (2009). "Dialogic public relations and resource dependency: New Jersey community colleges as models for web site effectiveness". Atlantic journal of communication, v. 17, n. 4, pp. 220-239.

https://doi.org/10.1080/15456870903210113

McCorkindale, Tina (2010). "Can you see the writing on my wall? A content analysis of the Fortune 50's Facebook social networking sites". Public relations journal, v. 4, n. 3, pp. 1-13.

https://goo.gl/T3dtSX

McCorkindale, Tina; Morgoch, Meredith (2013). "An analysis of the mobile readiness and dialogic principles on Fortune 500 mobile websites". Public relations review, v. 39, n. 3, pp. 193-197.

https://doi.org/10.1016/j.pubrev.2013.03.008

Muckensturm, Elizabeth (2013). Using dialogic principles on Facebook: How the accommodation sector is communicating with its' consumers. Clemson University. https://goo.gl/LkpHCw

Pieczka, Magda (2011). "Public relations as dialogic expertise?". Journal of communication management, v. 15, n. 2, pp. 108-124.

https://doi.org/10.1108/13632541111126346

Rybalko, Svetlana; Seltzer, Trent (2010). “Dialogic commu- nication in 140 characters or less: How Fortune 500 companies engage stakeholders using Twitter". Public relations review, v. 36, n. 4, pp. 336-341.

https://doi.org/10.1016/j.pubrev.2010.08.004

Taylor, Maureen; Kent, Michael L.; White, William J. (2001). "How activist organizations are using the Internet to build relationships". Public relations review, v. 27, n. 3, pp. 263-284. https://doi.org/10.1016/S0363-8111(01)00086-8

Toledano, Margalit (2017). “Emergent methods: Using netnography in public relations research". Public relations review, v. 43, n. 3, pp. 597-604.

https://doi.org/10.1016/j.pubrev.2017.03.007

Traynor, J.; Poitevint, M.; Bruni, B.; Stiles, H.; Raines, K.; Little, H. (2008). "On the ballot and in the loop: the dialogic capacity of campaign blogs in the 2008 election". In: Annual meeting of the Association for Education in Journalism and Mass Communication. Chicago.

Villanueva, Julián; Orihuela, José-Luis (2012). Los medios sociales en España: la visión de la alta dirección. Institute for Media and Entertainment; Universidad de Navarra; IESE Busines School.

https://goo.gl/yqCvmo

Waters, Richard; Lo, Kevin D. (2012). “Exploring the impact of culture in the social media sphere: A content analysis of nonprofit organizations' use of Facebook". Journal of intercultural communication research, v. 41, n. 3, pp. 297-319. https://doi.org/10.1080/17475759.2012.728772

Waters, Richard; Williams, Jensen M. (2011). "Squawking, tweeting, cooing, and hooting: analyzing the communication patterns of government agencies on Twitter". Journal of public affairs, v. 11, n. 4, pp. 353-363.

https://doi.org/10.1002/pa.385

Watkins, Brandi A. (2017). "Experimenting with dialogue on Twitter: An examination of the influence of the dialogic principles on engagement, interaction, and attitude". Public relations review, v. 43, n. 1, pp. 163-171.

https://doi.org/10.1016/j.pubrev.2016.07.002

Watkins, Brandi A.; Lewis, Regina (2014). "Initiating dialogue on social media: An investigation of athletes' use of dialogic principles and structural features of Twitter". Public relations review, v. 40, n. 5, pp. 853-855.

https://doi.org/10.1016/j.pubrev.2014.08.001

Wright, Donald K. (2005). "An analysis of the increasing importance of the role of the receiver in the communication process". In: $8^{\text {th }}$ Intl public relations research conf. Miami, Florida: The Institute for Public Relations.

http://195.130.87.21:8080/dspace/handle/123456789/816

Wright, Donald K.; Hinson, Michele-Drifka (2013). “An updated examination of social and emerging media use in public relations practice: A longitudinal analysis between 2006 and 2013". Public relations journal, v. 7, n. 3, pp. 1-39.

Xifra, Jordi; Huertas, Assumpció (2008). "Blogging PR: An exploratory analysis of public relations weblogs". Public relations review, v. 34, n. 3, pp. 269-275.

https://doi.org/10.1016/j.pubrev.2008.03.022 